\title{
MANAGING CONTINGENT LIABILITIES ARISING FROM PUBLIC PRIVATE PARTNERSHIP PROJECTS
}

\author{
George Nwangwu*
}

\begin{abstract}
All public infrastructure projects, irrespective of how they are procured, managed and financed, generate future liabilities. This becomes even more apparent under the Public Private Partnership arrangement. A number of these liabilities are subject to a high degree of uncertainty regarding when they will arise and the financial exposure involved when they do, and are therefore said to be contingent. Contingent liabilities have the potential to undermine national macroeconomic policy and cause significant economic harm when they crystalize. This article examines the legal and institutional mechanisms available in Nigeria to manage these liabilities and suggests ways for designing a PPP delivery process with inbuilt mechanisms for identifying, mitigating, tracking, and managing them.
\end{abstract}

Keywords: Public Private Partnerships, Contingent Liabilities, Risk Mitigation

DOI: https://dx.doi.org/10.4314/jsdlp.v9i2.5

\section{INTRODUCTION}

Public Private Partnerships (PPPs) are difficult to define. One of the principal reasons for this is that the concept is constantly evolving in various ways, in different sectors and different countries. Therefore, characteristics or boundaries of transactions or projects that may constitute PPPs are not closed; new PPP arrangements are constantly emerging. In recognition of this fact, the European Commission observed that PPP, as a concept, is still evolving and has divergent arrangements that may be adapted to suit the requirement of projects and project partners on a pragmatic basis. ${ }^{1}$ Also, the concept is amenable

* MBA (Oxford), PhD in Law (University of Hull), Former PPP Adviser, Federal Ministry of Finance, Government of Nigeria. Email: gnwangwu@gmail.com

1 EC Guidelines for Successful Public Private Partnerships (2003) < http:// ec.europa.eu/regional_policy/sources/docgener/guides/ppp_en.pdf $>$ accessed 17 September 2010. 
to different uses. For instance, it has been employed variously as a governance or management tool, ${ }^{2}$ as a development strategy ${ }^{3}$ or as a discursive term or language game. ${ }^{4}$ It has also been at the centre of political debate, allowing different parties the opportunity to use it in a manner that provides them with political leverage. ${ }^{5}$

Nevertheless, we may attempt a working definition that suits the topic of this article. PPPs may be defined as long-term relationships between public sector agencies and private sector entities under which the responsibility for any or all of the combination of designing, financing, construction, management and operation of public infrastructure and utilities that were traditionally undertaken by the public sector are contractually shared and jointly undertaken by both the public and private sector, usually in proportion to the kind of risks each party can best carry. ${ }^{6}$ This definition captures the essential elements of infrastructure PPPs, which is where PPPs are used to attract private sector finance for use in procuring public infrastructure. It might also be worth mentioning at this juncture that for this work, a transaction only qualifies as a PPP if there is a significant and optimal transfer of project risks between the public and private sectors.

All public infrastructure projects, irrespective of how they are procured, managed and financed, generate future liabilities. However,

2 This notion recognizes that PPP provides a novel approach to delivering goods and services to citizens and focuses on the organizational aspects of the relationship especially the cooperation between the private and public sectors. See GA Hodge and C Greve, "Public-Private Partnerships: An International Performance Review" (2007) Public Administration Review, May/June 545-58

3 This notion argues that PPP maximizes the benefits of development through collaboration and enhanced development. See, for example, the definition by the World Bank below.

4 As a language game it is assumed that PPP is used to cloud other strategies or purposes. For example, since privatization is a very contentious term, that a more acceptable term like PPP can be used to cloud the real intentions of the person employing the term. Generally, see NA Khanom, "Conceptual Issues in Defining Public Private Partnerships (PPP)" (2010) 6(2) International Review of Business Research 150-163; G. A. Hodge and C. Greve, "Public-Private Partnerships: An International Performance Review" supra for an analysis of the different approaches.

5 The Blair Government in the United Kingdom.

6 G. Nwangwu, "The Legal Framework for Public-Private Partnerships (PPPs) In Nigeria: Untangling the Complex Web”, (2012) 7(4) EPPPL 268-277. 
this becomes even more apparent under PPPs. ${ }^{7}$ A number of these liabilities are subject to a high degree of uncertainty, both as to when and if they will arise and as to the financial exposure involved when they do; hence they are said to be contingent. Contingent liabilities have the potential to undermine national macroeconomic policy and to cause significant economic harm when they crystalize. This article examines the legal and institutional mechanisms available within Nigeria for the management of these liabilities and suggests ways for designing a PPP delivery process with inbuilt mechanisms for identifying, mitigating, tracking, and managing them.

The article is organized into five sections. After this introduction, section 2 discusses the history and growth of PPPs in Nigeria. Section 3 evaluates the key legal and investment risks associated with PPP projects. Section 4 discusses practical approaches for managing and addressing contingent risks in PPPs in Nigeria. Section 5 is the conclusion.

\section{THE GROWTH OF PPPS IN NIGERIA}

Even though Nigeria has one of the biggest economies in Africa, the country's infrastructure is in really bad shape. The power sector in the country is marked by low-generating capacity relative to installed capacity. For instance, electricity generation ranges between 2,500 megawatts to about $4,000 \mathrm{MW}$ while estimated national consumption is in excess of 10,000 megawatts. $^{8}$ It is estimated that the country currently spends US $\$ 13$ billion in fueling power generators to cover the deficit in power needs ${ }^{9}$ and it is estimated that demand will double in the next few years. ${ }^{10}$ The state of the country's road network is poor with only about 15.3 per cent of its 195,200 kilometres paved and

7 See Vincent Tolani, "An Examination of Risk Allocation Preferences in PublicPrivate Partnerships in Nigeria" (2013) 2 (1) Afe Babalola University: Journal of Sustainable Development Law and Policy 206-221.

8 MO Yusuf, Private Sector Initiatives and Infrastructural Development in Nigeria (2004) <http://www.cenbank.org/out/Publications/occasionalpapers/rd/ 2004/Jos-02-4.pdf $>$ accessed 28 February, 2012.

9 NG Ekanem, "Nigeria the Most Dynamic PPP Market in Africa?" (2010) A Paper presented at the SADC PPP Forum and Network Launch in Midrand, South Africa, February 2010.

10 Ibid. 
about 28 per cent of these bad and un-motorable. ${ }^{11}$ The situation with the railway infrastructure is worse; the entire network is virtually moribund and outdated due to lack of upgrade and maintenance for over two decades. ${ }^{12}$ In many urban areas, hospitals, water supply, sewerage and waste disposal infrastructure, to mention a few, are virtually non-existent. Maintenance of the partially existing ones has been poor.

All these are being compounded by the twin problems of rapid population growth and urbanization. The investment required to meet the Government's Vision 2020 target is estimated at US\$35 billion for the power sector, US $\$ 13 \mathrm{~b}$ for the railways, US $\$ 5$ billion for the ports and US $\$ 3.5$ billion for the roads. ${ }^{13}$ It is a fact that the government is virtually unable to raise these large sums of monies required to meet this target. Consequently, it has set for itself a very ambitious target of attracting very huge private sector finance to meet these obligations. Therefore, a number of policies and regulations have been introduced in recent years to help actualize this objective. In furtherance of this, the country recently launched the National Integrated Infrastructure Master Plan (NIIMP) and the Economic Recovery and Growth Plan, which prioritized the provision of infrastructure and charts a new course for the delivery of infrastructure within the country.

This is not going to be an easy task because it is estimated that the country needs to invest between US\$6billion and US\$9billion every year for the next eight years to meet its infrastructure requirements. ${ }^{14}$ This is an enormous amount of money required within a very short time frame. It follows therefore that the primary motivation for the use of PPPs in Nigeria is to bridge the funding gap between funds available to government and the large amount of funds that is actually

11 U. Ohia, "Infrastructure Concessions in Nigeria: Challenges and Opportunities" (2011) A paper presented at the 5th Annual Diaspora Conference held in Abuja on 25-27 July 2011.

12 Recently the Abuja-Kaduna Railway line was commissioned and became about the only functional railway line in the country.

13 M. Ahmed, "Infrastructure Development for Nigeria: The PPP Imperative" (2011) < http://www.icrc.gov.ng/wp-content/uploads/2011/07/PPP-ForumICRC-DG-presentation-v4.pdf $>$ accessed 28 February 2012.

14 M. A. Animashaun, "Public Private Partnership as a Strategy of Infrastructure Finance in Nigeria" (2011) <http://njpg.pactu.edu.np/njpgfiles/4animashaun-mojeed-adekunle-public-private-partnership-as-a-policy-strategyof-infrastructure-financing-in-nigeria.html> accessed 28 February 2012. 
required to improve the country's derelict infrastructure. The other related factor is the failure and/or inefficiency of public authorities to provide much-needed public services. The government hopes that the private sector would be more efficient in providing these services.

The decision to resort to PPP was made easier by the fact that the country had gone through a privatization programme that lasted over three decades, which included a reform component encompassing the liberalization and deregulation of the economy. ${ }^{15}$ In essence, there was a partially liberalized economic environment in place; PPP was thus seen as the natural progression from privatization. Also, PPP did not carry "the baggage" which burdened the privatization programme simply because it did not lead to the complete transfer of ownership of assets from the government to the private sector (usually from overseas) and so people seemed more comfortable with it.

Nigeria being a developing country, with a moderate capital budget, an undeveloped capital market and not very buoyant private sector, had to rely on foreign private sector funding to realize its goals of providing infrastructure for its citizens. It is not surprising, therefore, that most of the early investment in infrastructure via PPP came through a collaboration between foreign investors and Nigerian businesses. The multilateral financial agencies also came in with a lot of support and finance. Some of the transactions that have been consummated so far are mainly in the transport sector, including a new airport terminal in Lagos, a new toll road in the Lekki area of Lagos, the seaports located around Lagos and the Niger Delta region of the country. There are a number of other projects currently in the pipeline like the light rail project for the Federal Capital Territory and Lagos and the concession of major road networks around the country. ${ }^{16}$

There is also a muted suggestion that the existing railway network will also be concessioned. In other sectors like housing, the Federal Capital Administration has concluded plans to concession the provision of infrastructure in certain areas of the capital city to some investors, and there are also ongoing deals being negotiated in the power sector. ${ }^{17}$

15 This programme was pursed through the Bureau of Public Enterprises (BPE). Under the programme, over 200 transactions were concluded.

16 NG Ekanem supra.

17 Most of the hitherto government-owned power assets are being completely divested through privatization. The only assets to be concessioned are the hydro power plants. 
Joint Ventures and Build Operate and Transfer (BOT) arrangements appear to be the most common PPP delivery mechanisms used in infrastructure projects in Nigeria, however, other popular PPP arrangements are Build Own Operate and Transfer (BOOT) and Design Build Finance Operate (DBFO). There have also been a number of concessions. ${ }^{18}$

It is clear therefore from the preceding that Nigeria has fully embraced the use of PPPs to finance infrastructure. The problem with this, however, is that investors require far more assurances to encourage them to participate in projects within the country. This has been a strong hindrance because investors (foreign and local) are wary of tying down their capital for 25-30 years without sufficient guarantees that they would be able to recoup their investments and make some profit. It does not also help that the risk of doing business in Nigeria is higher than in the more established economies. Therefore, prospective investors would like to see evidence or assurances that their investments will be safe and yield profitable returns. This has led to an increase in the use of sovereign guarantees and therefore the concomitant rise in contingent liabilities.

\section{LEGAL AND INVESTMENT RISKS IN PPPS}

One of the major advantages of PPP over other procurement models is the greater transfer of risks from the public sector to the private sector. ${ }^{19}$ It is important to note however that risk transfer does not eliminate the risk; it only reduces their economic cost when properly allocated to the appropriate party. ${ }^{20}$ Also, in reality, it is not feasible or wise to transfer all the risks that may arise in a project to the private sector. The essence of the "partnership" in PPP is the fact that parties are able to share the risks and rewards so that the party best able to assume a

18 The 26 Ports in the country were concessioned through the use of the "landlord tenant" model.

19 D. Grimsey and M. K. Lewis, "Evaluating the Risks for Public Private Partnerships for Infrastructure Projects" (2002) 20 International Journal of Project Management 107-118.

20 R. Marques and S. Berg, "Risks, Contracts and Private Sector Participation in Infrastructure" (2011) 137 (11) Journal of Construction Engineering and Management 925-932. 
particular risk shoulders it. ${ }^{21}$ Transferring all the risks to the private sector would greatly impair the viability of the project and also most likely its sustainability. This could lead to either the abandonment of the project by the private sector, or an escalation of the project cost thereby reducing its economic viability as, typically, the private sector will cost every risk allotted to it and charge a premium for them. Consequently, one may conclude that there is a correlation between the proper transfer and management of risk and the improvement of value for money on projects. The reason for this is simply because parties now become more conscious of transferred risks and are able to reduce either the probability of the risk occurring or the financial consequences if it does or both. ${ }^{22}$ Accordingly, it is important that every PPP project strives towards the proper allocation of risk between the public and private sectors.

The allocation of risk is done first of all on the basis that the party best able to assume a particular risk should bear it. Parties are best suited to bear a risk where the economic and social cost of bearing the risk is lower or where it would be easier or cheaper for one party to mitigate the particular risk, thereby lowering its economic and social cost. For instance, the private sector may choose to mitigate a number of its contractually assumed risks by buying insurance to cover them or by passing them down to other parties via subcontracts. Those risks that cannot be insured against or transferred through the use of subcontracts are inevitably dealt with through the use of special clauses in the contract to mitigate their impact. There are however cases where even after the risks have been apportioned to the private party; it may make social, political and sometimes commercial sense for the public sector to reduce the weight of the incidence of the risks that had been allocated to the private sector by taking some elements of those risks back. The reason for this is usually because the option of making the mitigation of these risks solely the responsibility of the private sector is more likely to increase the cost of the project. For instance, the cost of insurance can be very high or, in some cases, not even available for the particular risk. Also, from a public sector point of view, it may be important to mitigate risk in order to stimulate the private sector to

21 See Vincent Tolani, "An Examination of Risk Allocation Preferences in PublicPrivate Partnerships in Nigeria" (2013) 2 (1) Afe Babalola University: Journal of Sustainable Development Law and Policy 206-221.

22 Ibid. 
invest in projects, which it would not otherwise have considered for investment. Another reason may be to reduce costs to the private sector and consequently reduce tariffs and other burdens on its citizens.

It is important to note that it is this process of taking back some of the risks or the reduction of the incidence of these risks by the public sector that increases the potential for contingent liabilities arising in projects for the government.

\subsection{What are Contingent Liabilities?}

All public infrastructure projects, irrespective of how they are procured, managed and financed, generate future liabilities. ${ }^{23}$ Some of these, such as the cost of repaying loans denominated in the domestic currency or the costs of operating and maintaining an asset, are direct and predictable with a relatively high level of certainty. Others such as the cost of managing the consequences of an environmental incident related to an asset, addressing the effects of technological obsolescence and the crystallization of a sovereign guarantee, are subject to a high degree of uncertainty both in relation to when and if they will arise, as well as the financial exposure involved when they do. This is the reason why these latter types of liabilities are said to be contingent.

A contingent liability is a "future" obligation that may or may not arise. It depends on the outcome of an uncertain future event such as the eventuation of a risk, the judgment of a court, credit default, contractual warranty or contract default. Two types of contingent liabilities are recognized: Explicit liabilities, which are usually based on contractual agreements between the government and another party, for example a Power Purchase Agreement (PPA) or a contract to guarantee project design and implicit liabilities, which are based on a moral or political obligation to give governmental financial support when needed; for example, where the government invokes its step-in rights.

\subsection{PPPs and Contingent Liabilities}

It is a fact that contingent liabilities for government are more likely to arise in the case of PPPs than under traditional procurement for some

23 See Vincent Tolani, "An Examination of Risk Allocation Preferences in PublicPrivate Partnerships in Nigeria" (2013) 2 (1) Afe Babalola University: Journal of Sustainable Development Law and Policy 206-221. 
reasons, including:

a. The greater complexity and range of the contractual framework that applies in the case of PPPs than under traditional procurement;

b. The fact that the manner in which PPPs are structured, and the way that risks are allocated between the parties and the possibility of mitigating these risks through the use of guarantee instruments to incentivize investment by the private sector party are likely to increase the probability of contingent liabilities materializing;

c. The possibility that the public sector party in a PPP arrangement may fail to identify, document, track and monitor the full scale of the potential future liabilities associated with the projects;

d. The fact that due to the nature of the social services that PPPs provide, government retains an implicit obligation to bear the costs of stepping in to provide the contracted services if the private sector service provider fails. This is the case even where there is no explicit contractual commitment to do so.

Therefore, due to the social nature of PPP projects and the way they are structured, it means that governments would have to intervene from time to time. However, when governments intervene, their actions inevitably create liabilities. While some of these liabilities on the face of it appear to be only explicit, they also generate a degree of contingent liabilities. Some of government activities that generate contingent liabilities are public loans, loan guarantees, equity participation, subsidies, sovereign guarantees, and tax incentives. Others are viability gap funding, protection from competition, grants, and annual operating subsidies.

\subsubsection{Public Loans}

Under PPPs, the government may offer the private sector loans at very low or no interest rates at all. This is intended to lower the project cost. The loans may come as subordinated loans that supplement senior loans obtained from commercial banks to enhance the financial terms of the project. Also, the loans may be structured in a way that the private sector only becomes entitled to it if certain project risks materialize. In essence, the differential cost between these public loans and the cost of commercial loans are borne by government. The 
economic cost of these types of loans become more apparent where it is denominated in foreign currencies. In most cases, the liability arising from this loan is quantifiable and direct. However, government has an obligation to step in and repay the loan where the private sector defaults on its obligation to pay back either because of project failure, bankruptcy or delinquency. In these cases, government's obligation may now include repayment of the portion left unpaid by the private sector party.

\subsubsection{Loan Guarantees}

The public sector may decide to guarantee the loans of the private sector. This has the effect of lowering interest rates as the public sector technically borrows at a cheaper rate than the private sector. Since the government is a secondary obligor, its liability is contingent and only crystalizes in the event of the private sector party's default.

\subsubsection{Equity Participation}

Direct or indirect equity participation of the government in the projected company helps improve the project liquidity and has two advantages. The first is that it strengthens the assurance of the public and other stakeholders about the project and helps the project achieve better equity/debt gearing. In some cases, the public sector's right to dividend is subordinated to that of the private sector. Like all ordinary shareholders in the project, the equity contribution is at risk and is likely to be lost if the project fails. Note that there are also times where ordinary shareholders may become liable for the SPV liabilities outside of their investments in the business. This may occur where the corporate veil is pierced ${ }^{24}$ or where the shareholders have given personal or parent company guarantees to secure loans.

\subsubsection{Subsidies}

Where the actual cost of providing the service by the private sector is too high and likely to affect the demand for the service, the government

24 The corporations enjoy separate corporate personalities, and this is well entrenched in most common law jurisdictions. However, it is trite law that in deserving cases, the courts will pierce the corporate veil to hold shareholders labile for the actions of the company. 
may pay tariff subsidies to the private sector. The payment may be structured in such a way that it becomes payable only where income generated by the private sector falls below a certain minimum level. An alternative way of doing this is to allow the private sector crosssubsidize a less profitable service, activity or route with profitable ones. It is difficult to estimate with certainty the full economic costs of these subsidies and therefore the likelihood that it might spiral out of control is high.

\subsubsection{Sovereign Guarantees}

The government may guarantee the proper behaviour and/or respect of the commitments or obligations entered into by the public sector. The failure of the public sector to respect such commitments or obligations will give rise to a requirement to pay monetary compensation to the private sector. Also, sovereign guarantees may come in the form of "off-take guarantee" where the public sector guarantees that it will buy an agreed quantity of the service or product provided by the private sector. This is usual in power purchase agreements where the government or the off-taker agrees to pay capacity payments. It may also come in the form of traffic guarantee contracts. This involves guaranteeing either the traffic or revenue levels in the contract. The failure to reach this minimum levels triggers compensation from the public sector. In whatever form sovereign guarantees come, a contingent liability is created immediately it is given in a project as the occurrence of the guaranteed risk will trigger payment by the government.

\subsubsection{Tax Incentives}

The government may decide to give tax exemptions, tax holidays, rate reductions, tax abatements or tax credits in other to incentivize the private sector to go into certain businesses that it would not ordinarily have gone into. The exemptions may also extend to duty waivers, pioneer status, and so on. What this does is that it provides a cash flow cushion for the investor, which makes the project numbers work better. These tax incentives can be directed at specific financial aspects of the project. The problem with tax incentives in a country like Nigeria that operates a federal system of government is that there is likely to be conflicts between the national, states and local authorities who also have autonomy to tax within their respective jurisdictions. From a contingent liability perspective, the elimination or reduction of taxes 
payable by private sector parties has the effect of depriving the government of revenues, which it would have deployed for other uses. Where a blanket tax holiday is provided for a particular sector, it catalyses investments in that sector, attracting investments that would have otherwise been diverted into other businesses that are subject to full taxation. This may have a negative effect on government revenues at least in the short term until the previously tax-exempt sector becomes taxable.

\subsubsection{Viability Gap Funding}

This is a capital subsidy provided by the government to make projects financially viable, which would otherwise not be viable if left alone to the private sector to finance exclusively. For instance the Government of India has a scheme whereby the viability gap in PPP infrastructure projects is supported up to the tune of 20 per cent of the cost of the project and the state government or its agencies that own the project are also allowed to contribute an additional grant out of its own budget not exceeding a further 20 per cent of the cost of the project. ${ }^{25}$ Again, in very rare cases where a blanket viability gap is promised, it is likely to create contingent liabilities.

\subsubsection{Protection from Competition}

This comes in the form of an assurance given by the government to the private sector investor that it would not develop any competing infrastructure within a given period within a distance of the private sector's project. For instance, in a toll road project, the government may undertake not to build an alternative road that will compete or undercut the revenues of the private sector. Given the long-term nature of PPP agreements and the likelihood of constant population growth, this may be capable of stifling infrastructure growth and is very uncompetitive in nature. This is also likely to create contingent liabilities if government is compelled to grant the private sector beneficiary of this concession the first right of refusal to building additional infrastructure within the restricted areas. The loss of revenues and opportunities are unquantifiable.

25 Gujarat Infrastructure Development Board "Public Private Partnership" < http:/ /www.gidb.org/cms.aspx?content_id=96> accessed 30 March, 2012). 


\subsubsection{Grants}

Government may simply provide grants to the private sector investor or, in some cases, government grants may be combined with the payment mechanism to cover some of the capital cost. This may allow the required user charge to be kept at a level that is affordable to endusers. It may also be useful if the total project-funding requirement is larger than the market appetite for funding projects of such nature. This process has been used in light rail projects in the United Kingdom and the Gautrain project in South Africa. Such payments may also be performance linked.

\subsubsection{Annual Operating Subsidies}

This is an annual payment made by the public sector to a private sector operator where the revenues generated by the project is insufficient to give the private sector an acceptable return on its investment. Typically, project revenues are disbursed on the basis of an agreed "waterfall" model. Typically, operational expenses and loan repayments are given preference before any payments are made to equity investors. In cases where government offers annual operating subsidies, equity investors are promised payments to guarantee them an acceptable return on investment. In some cases, the payments are restricted to guarantee the repayment of debt holders and no more. The difference between operating subsidies and capital grants is that the use of subsidies may increase overall project costs since the project SPV has to fund the entire project cost.

\section{LEGAL AND INSTITUTIONAL FRAMEWORK FOR MANAGING CONTINGENT LIABILITIES}

The principal institution that is charged with the responsibility for managing contingent liabilities in PPP projects in Nigeria is the Debt Management Office (DMO). ${ }^{26}$ Other institutions like the Ministry of Finance and the budget office also play a role. The National Policy on PPPs recognizes this fact when it provides:

26 Nigeria National Policy on Public-Private Partnership (2017) p $9<$ https:// ppp.worldbank.org/public-private-partnership/library/nigeria-national-policyon-public-private-partnerships> accessed 12 August 2018. 
Together with the Ministry of Finance, the DMO will need to be satisfied that any contingent liabilities are manageable within Government's economic and fiscal forecasts. The DMO will need to be consulted in advance of project teams within an MDA which is considering the involvement of multilateral agencies such as IFC, MIGA or IDA in providing guarantees or other financial instruments. ${ }^{27}$

The DMO itself is established by the Debt Management Act $^{28}$ to prepare and implement a plan for the efficient management of Nigeria's external and domestic debt obligations and set guidelines for managing the country's risk and currency exposure with respect to all loans. ${ }^{29}$ PPP transactions will obviously require the Government of Nigeria to borrow both externally and internally as well as issue guarantees. Therefore, the DMO will necessarily be involved. Indeed, the Debt Management Act provides that the DMO shall "prepare a schedule of any other Federal Government obligations such as trade debts and other contingent liabilities both explicit or implicit and provide advice on policies and procedures for their management." ${ }^{30}$

The authority of the Ministry of Finance to be involved in the management of contingent liabilities is the Fiscal Responsibility Act. S. 47(1) of the Act gives power to the Minister of Finance, with the approval of the Federal Executive Council (FEC), to grant guarantees on behalf of the Government of the Federation. However, in doing this S. 47(2) provides that "any guarantee granted by the Minister shall be conditional upon the provision of a counter-guarantee equal to or higher than the guarantee obligation, provided that there are no overdue obligations from the requesting Government in the Federation to the guarantor and its controlled corporations.

It follows, therefore, that the Minister of Finance may only grant an application for a guarantee or other instrument that is likely to create a contingent liability after the approval of the FEC. However, the Minister must rely on the advice of the DMO in deciding on whether or not to grant such instruments. To enable it to provide such advice to the Minister of Finance in PPP projects, the DMO must conduct an

27 Ibid.

28 Debt Management Office (Establishment, etc.) Act No 18 of 2003.

29 ibid s 4.

30 Debt Management Act, s 6(1) (j). 
analysis of the project documents to identify, mitigate, and manage the contingent liabilities. The PPP Division of the Federal Ministry of Finance is also charged with the responsibility of identifying and tracking contingent liabilities arising from PPP projects.

In managing contingent liabilities, the aim of the DMO and the Ministry of Finance is not to drive out all contingent liabilities associated with PPPs, but to minimize them. This is because guarantees and contractual mechanisms that place appropriate risks with government are vital instruments in enabling private participation to make the maximum possible contribution to national infrastructure development. The aim of the extant framework is to ensure that government's fiscal exposures to contingent liabilities from PPPs are properly understood and only allowed where it makes a significant and proportionate contribution to national development. The framework also seeks to ensure that the aggregate contingent liabilities are kept within manageable limits.

The first step in managing contingent liabilities is to ensure the proper management of project risks. Given that the PPP contract is used to allocate project risks, it should be drawn up in such a way that it takes into consideration all eventualities that may affect the risk profile of the parties. Contracts that fail to address risk comprehensively are likely to raise the cost of infrastructure services to the final consumers. ${ }^{31}$ On a policy level, it can be useful to provide for risk allocation and mitigation guidelines in policy and legislative instruments. This will guide the parties through the contract negotiation process in the allocation, mitigation and pricing process before reducing them into contractual clauses as either, for instance, conditions or warranties or other contractual terms. There is also sometimes a need for the standardization of PPP contracts by creating templates as it may contribute towards greater transparency and reduce the incidence of corruption. However, such standardization may lead to a greater deal of rigidity in the PPP process.

It is also recommended that Nigeria introduce procedures and processes for managing and monitoring contingent liabilities from PPPs. Project planners and developers must consider the budgetary consequences of contingent liabilities compared with other funding

31 R. Marques and S. Berg Risks, "Contracts and Private Sector Participation in Infrastructure" (supra). 
options available for the project. The government must also consider the development of a contingent liability policy of guideline. A contingent liability policy not only provides for a structured method of dealing with contingent liabilities but may also have a positive influence on the ability of the government to attract more foreign direct investment to the country. It is essential that a key part of managing contingent liabilities is having a consistent method for allocating funds to projects and for verifying the need for government involvement.

Currently, there exists a lacuna in the coordinated management of contingent liabilities. There is no comprehensive database from which all indemnities, guarantees, and liabilities are managed. The government needs to develop a model to check the premiums charged for liabilities and calculating the capital required to offset them. Similarly, it is necessary for a comprehensive model to examine the balance sheet of the government's safety nets for public-private partnership projects (government exposure to the cash flow expected from the project), and a regular evaluation of risks that are derived from the probability that indemnities and guarantees granted by the government will be realized.

In considering explicit contingent liabilities, it is important to verify the need for government intervention, using a cost-benefit analysis, before granting an option for a "bailout". If government aid is required, steps should be taken to determine whether a contingent liability is the most efficient way to solve the problem. The duration of government intervention should be based on whether the cause for the intervention is temporary or permanent. For this reason, government officials should consider defining the liabilities in an explicit contract and assess the benefits and costs of such a move.

Where the government decides to provide any form of guarantee, such guarantee must be provided with absolute care because if it is misused, the public sector may be inadvertently creating a guarantee culture where the private sector seeks guarantees as an alternative to managing the risk itself. ${ }^{32}$ The use of guarantees may mean that the risk previously assumed by the private sector reverts back to the public sector. ${ }^{33}$ There is also the possibility that the cost and risk of such

32 United Nations Guide Book supra.

33 A. B. Alonso-Conde et al, "Public Private Partnerships: Incentives, Risk Transfer and Real Options" (2007) 16(4) Review of Financial Economics 335-349. 
guarantees are neither transparent nor well understood by the PPP stakeholders. ${ }^{34}$ It is also good practice to ensure that where these guarantees are used, provision should be made for the use of clawback clauses. These clauses ensure that the private sector gets only the benefits they need to make the project work and ensures that excess benefits are creamed off and given back to the taxpayers. The reasoning behind this is simply the notion that if risks are to be shared, then benefits should also be shared..$^{35}$

Also, when the construction phase of the project is completed, and the private sector begins the operation of the services, the public sector must put in place a risk monitoring and reporting system to ensure that the services are delivered to the public according to the contracted performance specifications. ${ }^{36}$ This will ensure that parties continue to assume allocated risks and, therefore, guarantee the continued viability of the project.

\section{CONCLUSION}

PPPs can play important roles in accelerating the development of infrastructure projects in developing countries. However, if not carefully designed and implemented, PPPs can occasion significant contingent liabilities. A number of these liabilities are subject to a high degree of uncertainty, both as to when and if they will arise and as to the financial exposure involved when they do.

In admitting projects with potential contingent liabilities, extreme care ought to be taken, as experience from other countries has demonstrated that the scale of total contingent liabilities can build up quickly if a successful PPP programme is established and that economic downturns or financial crises can result in fiscal liabilities from many projects crystallizing together within a short period of time. This has the potential to undermine national macroeconomic policy and to cause significant economic harm. This is why the PPP delivery process must have inbuilt mechanisms for identifying, mitigating, tracking, and managing contingent liabilities.

34 Ibid.

35 Ibid.

36 United Nations Guidebook supra. 